\title{
Anaesthesia for cardio- version: A comparison of propofol and thiopentone
}

Propofol (2,6 diisopropylphenol) $2.5 \mathrm{mg} \cdot \mathrm{kg}^{-1} \mathrm{~N}$ was compared with thiopentone $5 \mathrm{mg} \cdot \mathrm{kg}^{-1} \mathrm{IV}$ as an induction agent in anaesthesia for elective cardioversion. Thirty-five patients (ASA physical status $11-I I I)$ with atrial fibrillation were included. Thirty patients were randomized to receive propofol or thiopentone. Five patients were treased wice during the study period and anaesthetized with both agents (the first treatment according to the random order and the second with the agent not used on the first occasion). The induction characteristics and the haemodynamic response for propofol and thiopentone were similar. The success rate of cardioversion did not differ between the groups. Recovery times were shorter after propofol than after thiopentone with respect to ocular muscle balance, central integration and subjective sedation of patients. The incidence of side-effects did not differ between the groups. None of the patients reported any awareness during the procedure. All five patients sreated twice (with both agents) assessed the ancestheric procedure with propofol as being more pleasant than that with thiopentone.

\section{Key words}

ANAESTHETICS, INTRA VENOUS: propofol, thiopentone; HEART: cardioversion,

From the Department of Anaesthesiology, University of Turku, Turku, Finland.

Address correspondence to: Mika Valtonen MD, Turku University Central Hospital, Kiinanmyllynkatu 4-8, SF-20520 Turku, Finland.
Direct current countershock as a method for the restoration of sinus rhythm in cardiac arrythmias was first introduced by Lown, Amaringham and Newman in 1962. ${ }^{1}$ Patients undergoing cardioversion require a short anaesthetic and various anaesthetic agents have been used for the procedure. Thiopentone is considered to be a suitable anaesthetic for cardioversion ${ }^{2}$ and has also been the principal anaesthetic used at Turku University Central Hospital. However, its elimination half-life is fairly long (6-10 h) and this may cause unwanted subjective residual effects during recovery. ${ }^{3}$

Propofol (2,6-diisopropylphenol) is a new, rapidly acting intravenous anaesthetic. The rapid redistribution and metabolism of propofol, resulting in a short elimination half-life of approximately one hour ${ }^{4}$ suggest that the drug could be suitable for use in short procedures. Since its original cremophor EL-formulation was associated with a significant risk of anaphylactoid reactions, ${ }^{5}$ it was recently reformulated in an aqueous emulsion containing ten per cent soya bean oil. ${ }^{6}$ Initial animal studies have revealed anaesthetic properties similar to those of the original formulation. ${ }^{6}$

The aim of the present study was to compare the course of anaesthesia, the success rate of cardioversion and the recovery times in patients anaesthetized with propofol or thiopentone.

\section{Methods}

The study was carried out on 35 patients (ASA physical status II-III) undergoing elective cardioversion because of atrial fibrillation. Thifty patients were randomized to receive propofol or thiopentone. Five patients were treated twice during the study period and anaesthetized with both agents (the first treatment according to the random order and the second with the agent not used on the first occasion). The study was approved by the Hospital Ethical Committee and informed consent was obtained from each patient. Patient characteristics are given in Table $\mathrm{I}$.

Digoxin treatment was discontinued two days prior to the treatment. The patients fasted ovemight and were unpremedicated. Anaesthesia was induced either with 
TABLE I Patient characteristics (mean \pm SD)

\begin{tabular}{|c|c|c|c|}
\hline & \multicolumn{3}{|l|}{ Groups } \\
\hline & \multicolumn{2}{|l|}{ One treatment: } & \multirow{2}{*}{$\begin{array}{l}\text { Two treatments } \\
\text { Propofol and } \\
\text { Thiopentone } \\
(n=5)\end{array}$} \\
\hline & $\begin{array}{l}\text { Propofol } \\
(n=15)\end{array}$ & $\begin{array}{l}\text { Thiopentone } \\
(n=15)\end{array}$ & \\
\hline Age (years) & $55.2 \pm 7.6$ & $56.9 \pm 7.5$ & $53.8 \pm 9.8$ \\
\hline weight (kg) & $79.8 \pm 11.3$ & $82.5 \pm 13.6$ & $81.1=9.3$ \\
\hline Height (cm) & $173.1 \pm 7.5$ & $171.9 \pm 94$ & $171.2 \pm 16.4$ \\
\hline Male'Female (n) & $12 / 3$ & $11 / 4$ & $3 / 2$ \\
\hline ASA II/II (n) & $14 / 1$ & $12 / 3$ & $5 / 0$ \\
\hline
\end{tabular}

propofol $2.5 \mathrm{mg} \cdot \mathrm{kg}^{-1}$ IV or with thiopentone $5 \mathrm{mg} \cdot \mathrm{kg}^{-1} \mathrm{IV}$ given over $45 \mathrm{sec}$. When the patients no longer responded to command, the level of anaesthesia was considered adequate for d.c. shock. Oxygen was given through a non-rebreathing valve and face mask 1 min before induction of anaesthesia and thereafter. Assisted ventilation was instituted if the duration of apnoea exceeded 30 sec. The duration of anaesthesia was timed from the start of the injection of the induction agent to the moment at which the patient responded to command. All anaesthetics were given by the same anaesthetist (M.V.). The d.c. shock was administered about two minutes following the stan of anaesthetic injection. One electrode was placed below the apex of the heart and the other over the right sternal border. The initial energy discharge was $100 \mathrm{~J}$, which was increased to 200 and $360 \mathrm{~J}$ when necessary. No more than three shocks were given on each occasion. The duration of the procedure (i.e., the time from the start of anaesthesia to the last d.c. shock) was recorded.

Systolic (SAP) and diastolic (DAP) blood pressures were determined by indirect sphygmomanometric measurement two minutes before induction of anaesthesia (baseline), irnmediately after injection of the induction agent, immediately after d.c. shock, and after recovery (i.e., when the patients opened their eyes on command). Heart rate (HR) was registered simultaneously and the ECG displayed continuously on an oscilloscope.

Completeness of recovery was assessed during recovery period with three methods: subjective sedation was measured with visual analogue scale (VAS, $10 \mathrm{~cm}$ long, numbered from 0 to 10$),{ }^{7}$ the critical flicker fusion frequency (CFF) with a flickering red light emitting diode ( $3 \mathrm{~mm}$ diameter at $1 \mathrm{~m}$ distance from the subject) ${ }^{8}$ and extraocular muscle balance with a Maddox wing apparatus. ${ }^{9}$ These measurements were made before anaesthesia and $5,10,15$ and $30 \mathrm{~min}$ after recovery.

The presence of any side-effects during anaesthesia or the recovery period was noted. After recovery the patients were questioned regarding any awareness during or unplcasant memories associated with the procedure. The patients with two treatments (propofol and thiopentone, $n$ $=5$ ) were asked to give a personal assessment of the anaesthetic procedure.

Mean arterial pressure (MAP) was calculated as $1 / 3 \times$ $(\mathrm{SAP}+2 \times \mathrm{DAP})$ and rate pressure product (RPP) as SAP $X$ HR. Data are presented as mean values \pm standard deviation (SD). Haemodynamic data were compared using repeated analysis of variance and the differences between groups with Student's t test for parametric data and the Chi-squared test for nonparametric data. Recovery results were compared after analysis of variance with the $t$ test with approximation by Sattertwaite between groups and Newman-Keuls' test within groups. ${ }^{10}$

TABLE II Characteristics of induction and duration of procedure and anaesthesia in patjents induced with propofol or thiopentone (one treament, $n=30$ ) and in patients induced with propofol and thiopentone (two separate treatments, $n=5$ ), (mean $\pm S D$, Student's t test),

\begin{tabular}{|c|c|c|c|c|}
\hline & \multicolumn{4}{|l|}{ Groups } \\
\hline & \multicolumn{2}{|c|}{ One treatmen: } & \multicolumn{2}{|c|}{ Two treamens: } \\
\hline & $\begin{array}{l}\text { Propofol } \\
(n=15)\end{array}$ & $\begin{array}{l}\text { Thiopentone } \\
(n=15)\end{array}$ & $\begin{array}{l}\text { Propofol } \\
(n=5)\end{array}$ & $\begin{array}{l}\text { Thiopentont } \\
(n=5)\end{array}$ \\
\hline Total dose ( $\mathrm{mg} \cdot \mathrm{kg}^{\mathrm{w}}$ ) & $2.74 \pm 0.71$ & $5.16 \pm 0.36$ & $2.58 \pm 0.23$ & $5.17 \pm 0.21$ \\
\hline Induction time (s) & $72.0 \pm 20.0$ & $60.3 \pm 13.0$ & $63.0 \pm 12.0$ & $58.0 \pm 16.0$ \\
\hline Apnoea > 30 s (n) & 5 & 9 & 4 & 2 \\
\hline $\begin{array}{l}\text { Duration of apnoes (s) } \\
\text { Duration of }\end{array}$ & $61.0 \pm 5.5$ & $58.9 \pm 13.0$ & $58.8 \pm 2.5$ & $55.0 \pm 7.1$ \\
\hline procedure (min) & $5.6 \pm 2.5$ & $4.0 \pm 1.8$ & $6.4 \pm 3.2$ & $3.6 \pm 1.7$ \\
\hline $\begin{array}{l}\text { Time to orientation } \\
\text { (from the end of } \\
\text { procedure) (min) }\end{array}$ & $7.7 \pm 2.9$ & $6.5 \pm 4.4$ & $4.1 \pm 2.6$ & $4.1 \pm 3.3$ \\
\hline
\end{tabular}




\section{Results}

The groups were matched for age, weight, scx and ASA physical status (Table I). Induction characteristics for propofol and thiopentone were similar, as were the durations of the procedure and anaesthesia (Table II).

The results for haemodynamic variables are presented in Figure 1. The baseline values of heart rate differed significantly ( $p<0.05$ ) between the two groups. The decreases in mean arterial pressure after the induction of anaesthesia were similar in both groups but neither these nor the other variations in haemodynamic variables did achieve statistical significance within or between the two study groups. There were also no statistically significant differences in the success rate of cardioversion between the propofol and thiopentone groups (Tables III and IV).

Recovery times were shorter after propofol than after thiopentone with respect to the response to ocular muscle balance (Maddox wing), subjective sedation (VAS) and central integration (CFF). The recovery results are summarized in Figures 2 and 3. The incidence of side-effects did not differ between the groups (Table $V$ ). No major adverse reactions occurted either during or after anaesthesia. None of the patients reported any awareness during the procedure and all of them found the course of the anaesthesia acceptable. All five patients created twice (with both agents) assessed the anaesthetic procedure with propofol to be more pleasant than that with thiopentone.

\section{Discussion}

Propofol, in a dose of $2.5 \mathrm{mg} \cdot \mathrm{kg}^{-1}$ was found in this study to produce similar induction characteristics to those of thinpentone at. $5 \mathrm{mg} \cdot \mathrm{kg}^{-1}$. Earlier studies have reported greater arterial hypotension with propofol than with thiopentone, ${ }^{11-14}$ and that it is more profound in elderly patients and in those with ischaemic heart disease. ${ }^{15,16}$ The present results, however, show only a slight decrease of similar magnitude with both agents. In our view three factors may account for this finding: no premedication, slow injection of the induction agent and the compensato-

TABLE III Energy level required and success rate of cardioversion in patients induced with propofol or thiopentone (one treatment, $n=30$ ), (Chi-square test).

\begin{tabular}{|c|c|c|c|}
\hline & \multicolumn{3}{|l|}{ Groups } \\
\hline & \multirow{2}{*}{$\begin{array}{l}\text { Energy } \\
\text { Level } \\
\text { (S) }\end{array}$} & \multicolumn{2}{|c|}{ One treatment: } \\
\hline & & $\begin{array}{l}\text { Propofol } \\
(n=I 5)\end{array}$ & $\begin{array}{l}\text { Thiopenone } \\
(n=15)\end{array}$ \\
\hline \multirow[t]{3}{*}{ Successful cardioversion (n) } & 100 & 1 & 6 \\
\hline & 200 & 7 & 7 \\
\hline & 360 & 3 & 0 \\
\hline \multicolumn{2}{|c|}{ Unsuccessful cardioversion (n) } & 4 & 2 \\
\hline
\end{tabular}

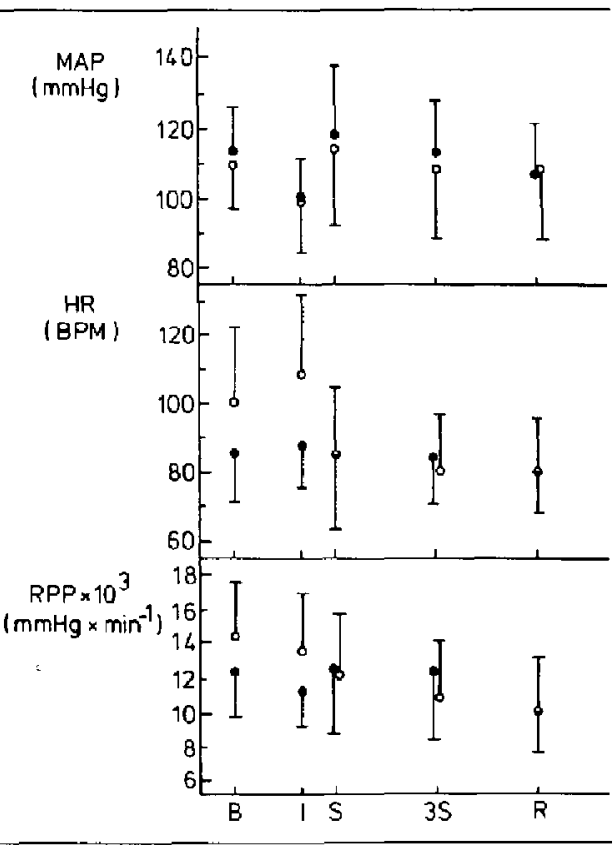

FIGURE 1 Mean arterial pressure (MAP), heart rate (HR) and rate pressure product (RPP) before induction of anzesthesia (B), immediately after injection of the induction agemt (l), after d.c. shock (S), 3 min after d.c. shock (3S) and after reccvery (R) in propofol (O) and thioentone (O) groups (mean $=S D$, repeated measures ANOVA).

ry effect of d.c. shock on the hypotension induced by the induction agent.

The difference in the baseline values of heart rate found between groups is explained by the inclusion of three patients with slow heart rates $\left(60-70\right.$ beats $\left.-\mathrm{min}^{-1}\right)$ in the

TABLE IV Energy level required and success rate of cardioversion in patients induced with propofol and thiopentone (two separate treatments, $\mathrm{n}=5$ ). Patients are numbered from one to five and each patient represents the same number in both treatments (Chi-square test).

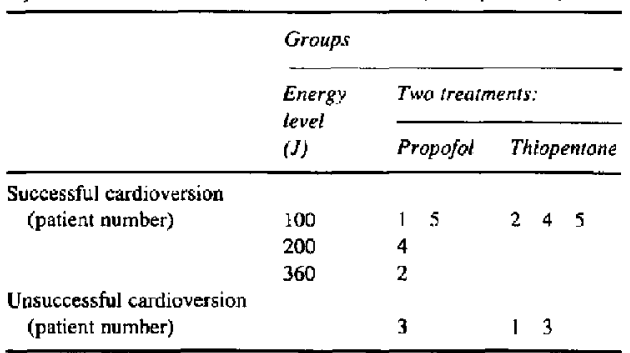




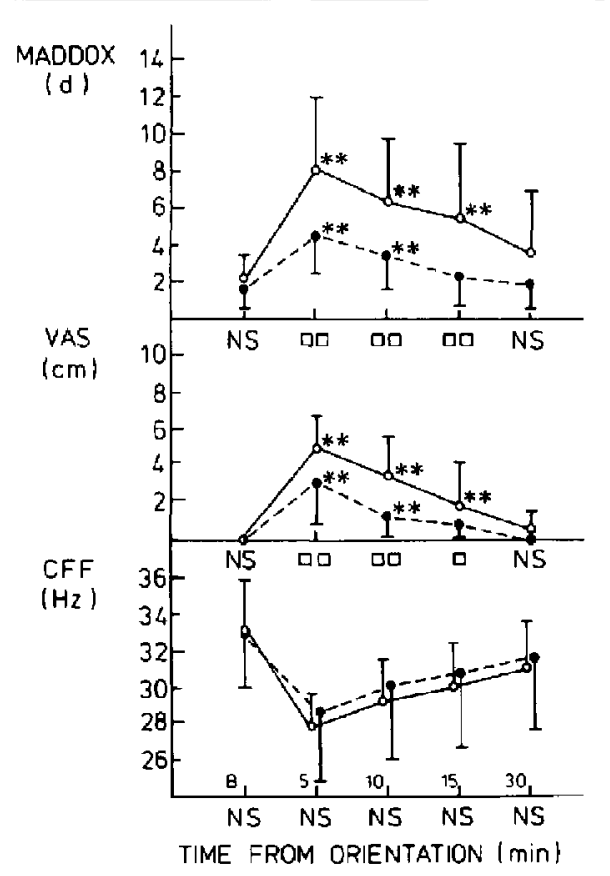

FIGURE 2 Completeness of recuvery assessed by Maddox wing (Maddox), visual analogue scale (VAS) and critical flicket fusion (CFF) as a function of time in propofol $(O)$ and thiopentone $(O)$ groups (analysis of yariance, $t$ test with approximation by Sattertwaite and Newman-Keuls). "* $p<0.01$ (within groups, compared with basclime valuc $=$ B). $\square_{p}<0.05$ (between groups). $\square \square p<0.01$ (bctwecn groups). NS = not significant

propofol group. The rate pressure product shows a similar difference.

Although the success rate of cardioversion did not significantly differ between groups (Tables $\mathrm{Wl}$ and IV), propofol appeared to increase the energy requirement for successful cardioversion more than thiopentone. However, the reason for this finding remains unclear and whether propofol truly have some effect to the threshold of the electrical irritation of heart needs thus further evaluation.

Measurements carried out with the Maddox wing and visual analogue scale (VAS) indicate shorter recovery times after propofol than after thiopentone. Although the residual effects of both anaesthetics were also seen in measurements with critical flicker fusion frequency (CFF), this test appears to be less sensitive in differentiating between various drug effects (Figure 2). In the patients treated twice (propofol and thiopentone, $n=5$ ) all three methods (Maddox wing, VAS, CFF) could

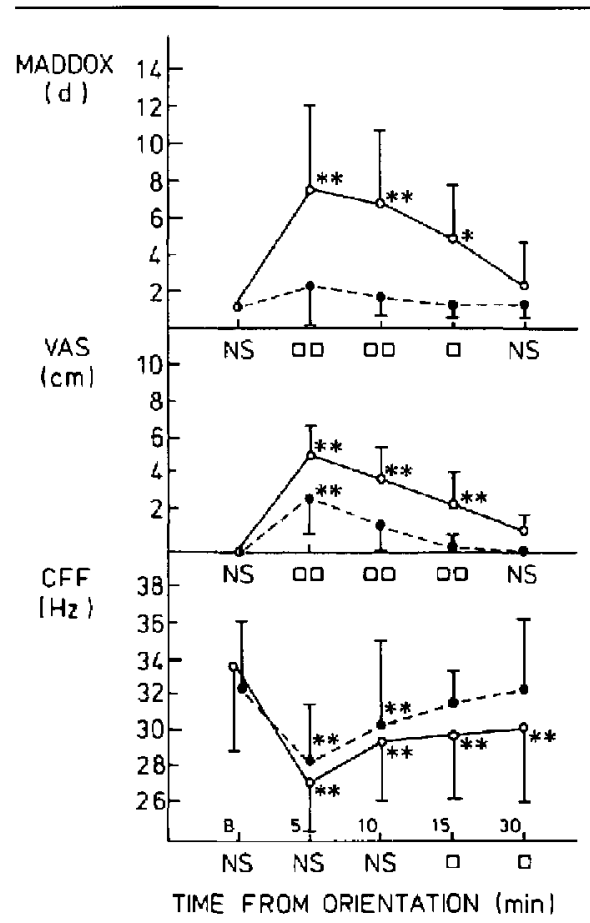

FIGURE 3 Completeness of recovery assessed by Maddor wing (Maddox), visual analogue scalc (VAS) and critical flicker fusion (CFF) as a function of time in patients treated twice (propofol $\rightarrow$ and thiopentone $O$ ) (analysis of variance, $t$ test with approximation by Sattertwaite and Newman-Keuls). ${ }^{*} p<0.05$ (within groups compared with baseline value $=B$ ), ${ }^{*} p<0.01$ (within groups compared with baseline value $=B$ ),$\square_{p}<0.05$ (between groups), $\square \square$ p $<0.01$ (between groups). NS = nọt significant

indicate more residual effects after thiopentone than after propofol. It is probable that the subjective preference of these five patients towards propofol rather than thiopentone is due to the lesser residual effects experienced with propofol.

In conclusion, propofol was found to be similar to thiopentone in both induction characteristics and the immediate haemodynamic response. Recovery times from anaesthesia for cardioversion were shorter with propofol. In day-case anaesthesia (short procedure with little or no subsequent pain), rapid recovery of consciousness is a clear advantage. The new intravenous anaesthetic agent propofol appears to provide this desirable feature and it seems to be a suitable altemative to thiopentone as an induction agent for patients undergoing elective cardioversion. 
TABLE $V$ Incidence of side-effects during anaesthesia and recovery (Chi-square test).

\begin{tabular}{|c|c|c|c|c|}
\hline & \multicolumn{4}{|l|}{ Groups } \\
\hline & \multicolumn{2}{|c|}{ One treatment: } & \multicolumn{2}{|c|}{ Two sreaiments: } \\
\hline & $\begin{array}{l}\text { Propofol } \\
(n=I 5)\end{array}$ & $\begin{array}{l}\text { Thiopentone } \\
(n=15)\end{array}$ & $\begin{array}{l}\text { Propofot } \\
(A=5)\end{array}$ & $\begin{array}{l}\text { Thiopentome } \\
(n=5)\end{array}$ \\
\hline \multicolumn{5}{|l|}{ Anaesthesia: } \\
\hline Excitation (n) & 4 & 2 & 1 & 1 \\
\hline Pain on injection (n) & 2 & 0 & 1 & 0 \\
\hline Recovery (n) & $3^{*}$ & $1+$ & 0 & 0 \\
\hline
\end{tabular}

*Cough, restlessness.

†Cough.

\section{Acknowledgement}

Propofol was supplied by ICI-Pharma. Helsinki.

\section{References}

1 Lown B, Amaringham R, Newman J. New method for terminating cardiac arrythmias. JAMA 1962; 182: 548-52.

2 OrkoR. Anaesthesia for cardioversion. A comparison of diazepam, thiopentone and propanidid. $\mathrm{Br} J$ Anaesth 1976; 48: 257-62.

3 Dundee JW. Intravenous anacsthesia and the need for new agents. Postgrad Med J 1985; 61 (Suppl 3): 23-7.

4 Adam H, Briggs L, Bahar M, Douglas E. Dundee J. The pharmacokinetic evaluation of ICI 35868 in man. Single induction dose with different rates of infusion $\mathrm{Br} J$ Anacsth 1983; 55; 97-103.

5 Briggs LP, Clarke RSI, Waikins $J$. An adverse reaction to the administration of disopropofol (Diprivan). Anaesthesja 1982; 37: 1099-1101.

6 Glen $J B$, Hunter SC. Pharmacology of an emulsion formulation of ICI 35868. Br J Anaesth 1984; 56: 617-25.

7 Maxweil $C$. Sensitivity and accuracy of the visual analogue scales: a psycho-physical classroom experiment. Br J Clin Pharmacol 1978; 6: 15-24.

8 Smith J, Misiak $H$. Critical flicker frequency (CFF) and psychotropic drugs in normal human subjects - a review. Psychopharmacol 1976; 47: 175-82.

9 Hannington-Kiff $J$. Measurement of recovery from outpatient general anaesthesia with simple ocular test. Br Med J 1970; 3: 132-5.

10 Winer $B J$. Statistical principles in experimental design, 2nd ed. New York (Mcgraw Hill), 1971; 523-46.

11 Coates DP, Prys-Roberts C, Spelina KR, Monk CR, Norley 1. Propofol (Diprivan) by intravenous infusion with nitrous oxide: dose requirements and haemodynamic effects. Postgrad Med J 1985; 61 (Suppl 3): 76-9.

12 Fahy LT, van Mourik GA, Utting JE. A comparison of the induction characteristics of thiopentone and propofol (2,6-di-isopropyl phenol). Anaesthesia 1985; 40: 939-44.
13 Mackenzie N, Grant IS. Comparison of the new emulsion formulation of propofol with methohexitone and thiopentone for induction of anaesthesia in day cases. $\mathrm{Br} \mathrm{J}$ Anuesth 1985; 57: 725-31.

14 McCollum JSC, Dundee JW. Comparison of induction characteristics of four intravenous anaesthetic agents. Anaesthesia 1986; 41: 995-1000.

15 Patrick MR, Blair IJ, Feneck RO, Sebel PS. A comparison of the haemodynarnic effects of propofol (Diprivan) and thiopentone in patients with coronary artery disease. Postgrad Med J 1985; 61 (Suppl 3): 23-7.

16 Stephan H, Sontuag H, Schenk HD. Kettler D, Khambatta $H J$. Effects of propofol on cardiovascular dynamics, myocardial blood flow and myocardial metabolism in patients with coronary anery disease. Br J Anaesth 1986 ; 58: $969-75$.

\section{Résumé}

Le propofol $\left(2,6\right.$ diisopropylphenol) $2.5 \mathrm{mg} \cdot \mathrm{kg}^{-1} \mathrm{IV}$ a été comparé au thiopentone $5 \mathrm{mg} \cdot \mathrm{kg}^{-1} \mathrm{IV}$ comme agent d' induction pour des cardioversions electives. Trente-cing patients (ASA classe (I-III) avec une fibrillation auriculaire ont été inclus. Trente patients ont eté randomises afin de recevoir du propofol ou du thiopentone. Cinq patients ont été traités deux fois durant l'étude et anesthésiés avec les deux agents lla première fois l'agent fut choisi au hasard, la deuxieme fois l'autre agent fut utilisél. Les caractéristiques de l'induction et la réponse hémodynamique étaient similaires avec le propofol et le thiopentone. Le taux de succès de la cardioversion n'érait pas différent enire les groupes. Les temps de récupération étaient plus courts après propofol qu'après thiopentone concernant l'équilibre musculcire oculaire, l'intégration centrale et la sédation subjective des patients. $L$ 'incidence des effets secondaires n'était pas différente entre les groupes. Aucun des patients n'a rapporté avoir eu de rappel lors de la procédure. Tous les patients traités deux fois avec les deux agents ont évalué la procédure anesthésique avec le propofol comme etant plus plaisante quiavec le thiopentone. 